\title{
Effect of Xanthosoma Sagittifolium Powder, Water and Mixing Time on Texturized Vegetable Protein Properties
}

\author{
Triana Lindriati \\ dept of Agricultural Product \\ Technology \\ University of Jember \\ Jember \\ lindriatitriana@unej.ac.id
}

\author{
Herlina \\ dept of Agricultural Product \\ Technology \\ University of Jember \\ Jember \\ linaftp@yahoo.com
}

\author{
Hari Arbiantara \\ dept of Mechanichal Engineering \\ University of Jember \\ Jember \\ hariarbi@google..com
}

\begin{abstract}
Abstract Texturized Vegetable Protein (TVP) is made from soy protein by extrusion method which is intended to replace meat. The addition of Xanthosoma Sagitifolium Powder (XSP) in the TVP matrix is expected to improve its functional properties. The objective of this study is to determine the effects of XSP proportion, mixing time and water addition to the TVP water holding capacity (WHC), oil holding capacity (OHC), texture and protein solubility. The result shows that XSP proportion, mixing time and water addition, significantly affect on WHC, OHC, texture and protein solubility of TVP $(p<0.05)$. The effect of XSP addition on WHC is increase when added to $20 \%$, but decrease after added more than $20 \%$. The effect of XSP addition to texture show the same pattern, on $\mathrm{OHC}$ value is random and on protein solubility is lowering. There are decreases of WHC, OHC, protein solubility and increase of texture when mixing time increase from 6 to 18 minutes. The effect of water addition on WHC, $\mathrm{OHC}$ and protein solubility is significantly decrease and texture is increase.
\end{abstract}

Keywords-Meat analog, , Oil Holding Ccpacity, Protein Solubility, Texture, Water Holding Capacity, Xanthosoma Sagittifolium,

\section{INTRODUCTION}

Meat analog is a food product that usually made from vegetable protein. The product has texture, flavor, appearance and/or chemical characteristics approximate of animal meat. The other advantages of meat analog are healthier and cheaper than meat and refer to environmentally friendly product. The main function of meat analog is to replace meat in our diet. It can be consumed directly or added in processed meat products such as sausage, meatball, nugget. One kind of meat analog is TVP that usually use in processed meat product to replace meat, that can promote the ability to retain water and moisture during cooking, reheating, freezing and thawing.

TVP usually made from soy protein and extrusion techniques are used in TVP production. Shear stress and high temperatures cause by the screw rotation resulting in intensive mixing and melting of protein and carbohydrate macromolecules [1]. Extrusion is usually used for large-scale production, therefore making TVP is rarely applied in daily cooking. Pasta machine is a simple extruder which is widely used in daily cooking activities. Application of this machine in TVP making facilitates the meat analog provision.

The properties of TVP depend on composition of major ingredients, moisture content and extrusion conditions. In the TVP matrix, protein can produce a fine structure [2], while carbohydrate supported the structure and increase texture [3, 4]. Addition of carbohydrate into a meat analog matrix can result in fibrous characteristic and probably increase texture.

Xanthosoma sagittifolimum powder (XSP) is a potential carbohydrate source that can be used in TVP production. The yam has high starch content $74,66 \pm 0,66$ to $80,46 \pm 0,62 \%$, and various types of phytochemicals, that are dioscorine alkaloid, diosgenin saponin and flavonoid which has many health benefits [5]. The other benefit of the yam is the cultivation is easy, even can grow under less favorable land conditions. The use of XSP in TVP production is to improve physical properties, functional properties and health benefit.

The objectives of this study were to determine the effects of water addition, mixing time and XSP percentage on texture, water holding capacity (WHC), oil holding capacity (OHC) and protein solubility of TVP. The production of TVP in this research used Houseware pasta machine.

\section{METHODS}

\section{A. Time and place}

This research was started in May 2017 and finish in September 2017. This research was carried out in laboratories in the Agricultural Product Techology Department, Faculty of Agricultural Technology, University of Jember.

\section{B. Raw materials}

The material used as raw materials in TVP production were Concentrate Soy Protein (CSP) and Xanthosoma sagittifolimum powder (XSP). CSP obtained from a local shop (NURA). The XSP was produced from Xanthosoma sagittifolimum yams according to [6] with modification on dipping solution which was 200 ppm sodium chloride used rather than sodium metabisulphate $20 \mathrm{ppm}$. The proximate analysis result showed that CSP contains protein about $66.1456 \%$, lipid of $0.1612 \%$, water of $5.7496 \%$, ash about $4.4357 \%$ and carbohydrate of $27.9436 \%$, whereas XSP contains protein about $2.3667 \%$, lipid of $0.3264 \%$, water of $8.2715 \%$, ash about $4.4217 \%$ and carbohydrate of $84.6137 \%$. Mineral water (aqua) was used to adjust the moisture.

\section{Experimental design}

There were three parts of the research. Every part used one factorial completely randomized design with three replications. Analysis of variance with 0.05 significance level was used and average of each treatment was compared using a Tukey 
multiple comparison test. The effect of XSP proportion $(0,20$, $40,60$ and $80 \%)$ was studied at the constant mixing time (12 minute) and the constant water addition (120\%). The effect of mixing time $(6,9,12,15$ and 18 minutes) was studied at constant XSP proportion (30\%) and water addition (120\%). The effect of water addition $(80 \%, 100 \%, 120 \%$ and $140 \%$ $\mathrm{w} / \mathrm{w}$ ) was studied at the constant mixing time (12 minute) and constant XSP proportion (30\%). Statistical analysis was performed using MINITAB V14.0 for Windows.

\section{TVP preparation}

XSP and CSP were blended and water was added in the extruder. The Houseware pasta making machine (healthy power noodle, Fastworld) was used. The dough was mixed for certain time and then extruded wherein the extruder's die modified before. The extrusion process was done without heating. The XSP proportion, water addition and mixing time were varied according to the experimental design. The wet extrudat was blanched at $100^{\circ} \mathrm{C}$ for 30 minutes and continued with drying process at $50^{\circ} \mathrm{C}$ for 20 hours (regulating oven).

\section{E. Texture Analysis}

The texture was measured using Rheotex Type SD-700 (Sun Scientific Co-LTD) wherein the head was set $0,15 \mathrm{~mm}$. Dry TVP was boiled in water for 15 minutes. Each sample was measured for five replications and the result was presented in gram $/ \mathrm{mm}$.

\section{F. Protein solubility}

The method of [7] was applied to the measurement. The TVP was weighed about $500 \mathrm{mg}$ and put it into $150 \mathrm{ml}$ beakers. $0.1 \mathrm{M} \mathrm{NaCl}$ was added and stirred to produce smooth paste. The volume was adjusted to $40 \mathrm{ml}$ total volume by $0,1 \mathrm{M}$ $\mathrm{NaCl}$. The dispersion was stirred on a magnetic stirrer for 1 hours wherein the beaker was covered with aluminium foil. The dispersion was placed in a $50 \mathrm{ml}$ volumetric flask, then $0,1 \mathrm{M} \mathrm{NaCl}$ was used to adjust the volume. The dispersion was centrifuged for 30 minutes at $3000 \mathrm{rpm}$ and supernatant was obtained by filtering with Whatman No. 1 filter paper. The protein content of the filtrate was observed by biuret method. The protein solubility of TVP was calculated as:

Protein solubility $(\%)=\frac{\text { Supernatant protein conc }\left(\frac{\mathrm{mg}}{\mathrm{mL}}\right) \times 50}{\text { Sample wt }(\mathrm{mg}) \times \frac{\text { Sample protein content }(\%)}{100}} \times 100$

\section{G. Water and Oil - Holding Capacity (WHC and OHC).}

Measuring WHC and $\mathrm{OHC}$ in this research used a modification of [8] method. The sample used was one gram of TVP, which is stirred in $10 \mathrm{ml}$ of distilled water or coconut oil ("dorang" local product). Before centrifuged, 2 minutes vortex was done to disrupt TVP structure. The centrifuge was done at $3000 \mathrm{rpm}$ for 30 minutes. WHC or OHC was presented as the weight of water or oil retained in $1 \mathrm{gr}$ of the sample.

\section{RESULTS AND DISCUSSION}

\section{A. The Effect of XSP proportion}

According to analysis of variance, enhancement of XSP proportion significantly affected on $\mathrm{WHC}, \mathrm{OHC}$ and texture $(\mathrm{P}<0,05)$. Table 1 shows, there is tendency in increasing WHC at the range of XSP proportion of $0 \%$ to $20 \%$. But at the range of XSP proportion from $20 \%$ to $80 \%$ different tendency are seen wherein it is decreasing. According to [9], WHC is a protein-water interaction, which is associated with the ability of the protein matrix to retain water that absorb, bound, hydrodynamic, capillary and physical entrapped, therefore the amount of protein within blends may influence the WHC. A different trend is shown when XSP was added from $0 \%$ to $20 \%$, this is probably because of carbohydrate-protein interaction. The same trend was also shown in our previous study, wherein the addition of $20 \%$ tapioca in the ISP matrix occurred repulsive interaction between carbohydrates and protein [10].

Table 1. WHC, OHC and Texture value of TVP with variation of XSP proportion.

\begin{tabular}{cccc}
\hline XSP proportion & WHC (\%) & OHC (\%) & $\begin{array}{c}\text { Texture } \\
(\mathbf{g r} / \mathbf{m m})\end{array}$ \\
\hline $0 \%$ & $166.2431 \pm$ & $56.7522 \pm$ & $34 \pm 0.7^{\mathrm{b}}$ \\
& $3.2069^{\mathrm{c}}$ & $2.4863^{\mathrm{c}}$ & \\
$20 \%$ & $201.9078 \pm$ & $77.9090 \pm$ & $9.5 \pm 0.4^{\mathrm{a}}$ \\
& $5.6903^{\mathrm{d}}$ & $1.9193^{\mathrm{d}}$ & \\
$40 \%$ & $150.3658 \pm$ & $25.9354 \pm$ & $52 \pm 1.1^{\mathrm{c}}$ \\
& $2.0919^{\mathrm{b}}$ & $2.5333^{\mathrm{a}}$ \\
$60 \%$ & $120.6305 \pm$ & $32.6598 \pm$ \\
& $9.2056^{\mathrm{a}}$ & $1.8734^{\mathrm{b}}$ & $127.6 \pm 0.4^{\mathrm{d}}$ \\
$80 \%$ & $118.5381 \pm$ & $56.1930 \pm$ & $207.8 \pm 10.9^{\mathrm{e}}$ \\
\multicolumn{4}{c}{$1.5219^{\mathrm{c}}$} \\
\hline Note:"Means in the same column/row with different superscript differ significantly $(\mathrm{P}<0.05)$.
\end{tabular}

The variation of $\mathrm{OHC}$ value is random, wherein there is tendency of increasing $\mathrm{OHC}$ in the range of XSP added $0 \%$ to $20 \%$, but decreasing at the range of $20 \%$ to $40 \%$ and then increasing again at the range of $40 \%$ to $80 \%$. The highest $\mathrm{OHC}$ value obtain from $20 \%$ XSP proportion. This is probably because there are many factors that influence on the ability of the TVP matrix in the holding oil. TVP with high oil capacity is chosen in sausage production. The TVP, which can bond fat and water are preferred [11].

There is tendency in decreasing texture when XSP added $20 \%$, but increasing texture occur when XSP added $20 \%$ to $80 \%$ (Table 1). The research by [4] showed, decreased of soy protein isolated resulted in a lower expansion ratio, but higher of texture and fibrous characteristic. According to [3] toughness was decreasing as the amount of protein in the extrudate was increased. The decrease of texture when XSP added $20 \%$ probably because of repulsive carbohydrateprotein interaction.

\section{B. The Effect of Mixing Time}

Table 2. WHC, OHC and Texture value of TVP with variation of mixing time.

\begin{tabular}{cccc}
\hline Mixing time & WHC $\mathbf{( \% )}$ & OHC & Texture \\
\hline 6 minutes & $199.1470 \pm$ & $52.5399 \pm$ & $22.8 \pm 1,5^{\mathrm{a}}$ \\
& $8.3579^{\mathrm{b}}$ & $0.9682^{\mathrm{b}}$ & \\
9 minutes & $212.2166 \pm$ & $52.9138 \pm$ & $24.7 \pm 1.3^{\mathrm{a}}$ \\
& $12.0586^{\mathrm{b}}$ & $2.1523^{\mathrm{b}}$ & \\
12 minutes & $196.6191 \pm$ & $50.8116 \pm$ & $21.8 \pm 1.7^{\mathrm{a}}$ \\
& $1.4290^{\mathrm{b}}$ & $1.0301^{\mathrm{b}}$ & \\
15 minutes & $176.3334 \pm$ & $40.9888 \pm$ & $23.8 \pm 0.4^{\mathrm{a}}$ \\
& $2.8464^{\mathrm{a}}$ & $1.3581^{\mathrm{a}}$ & \\
18 minutes & $177.3356 \pm$ & $39.4941 \pm$ & $50.2 \pm 0.4^{\mathrm{b}}$ \\
& $3.3204^{\mathrm{a}}$ & $0.6604^{\mathrm{a}}$ & \\
\hline Note:"Means in the same column/row with different superscript differ significantly $(\mathrm{P}<0.05)$.
\end{tabular}

According to analysis of variance, variation of mixing time significantly affected on WHC, OHC and texture $(\mathrm{P}<0.05)$. When mixing time increase from 6 to 18 minutes, the WHC and $\mathrm{OHC}$ value is decreasing but texture value increase (Table 2). Increase of mixing time prolonged shear time resulted in a 
damaged structure of the TVP matrix. The research of [12] and [1] agrees with our result wherein prolonged shear time resulted in the torque curve trend as the sharp torque increased and decreased of stress and strain. The damage structure in our research is showed by leveling down the $\mathrm{OHC}$ and $\mathrm{WHC}$ value whilst increased of texture. However, there was no damage before 12 minutes of mixing time. These had been shown by no significant change in $\mathrm{WHC}$ and $\mathrm{OHC}$ value as well as texture (Table 2).

\section{The Effect of Water Addition}

Increase of water added in the TVP dough was significantly decreased WHC and $\mathrm{OHC}$ value and increased of texture $(\mathrm{p}<0.05)$. Table 3 shows that the decrease of the WHC and $\mathrm{OHC}$ are not significant when water added $70 \%$ and $90 \%$ as well as when added $110 \%, 130 \%$ and $150 \%$. The increase of texture is not significant when water added $130 \%$ and $150 \%$.

An important role of water in TVP making is on the formation of protein fibrous structure. There are different appearances between TVP produced with different water content. The research by [13], who had studied protein-protein interaction of soy protein isolates from extrusion processing in different water content, showed that there are no differences in protein-protein interaction that contributed to the texturization although the appearances is different.

\section{Protein Solubility}

Solubility is an important target parameter to evaluate the nutritional value of protein-based product [14]. Usually digestibility of mild extrusion protein-based food product will enhance. It can be evaluated from protein solubility.

Protein solubility significantly increases when XSP proportion enhances Wherein $80 \%$ XSP proportion result in the high protein solubility (Table 3). An increase of XSP proportion decreases protein content. This is probably causing disruption in the formation of protein-protein matrix and make the protein more soluble.

Table 3. WHC, OHC and Texture value of TVP with variation

\begin{tabular}{cccc}
\multicolumn{4}{c}{ of water addition. } \\
$\begin{array}{c}\text { Water } \\
\text { Addition }\end{array}$ & WHC (\%) & OHC (\%) & $\begin{array}{c}\text { Texture } \\
\text { (gr/cm) }\end{array}$ \\
\hline $70 \%$ & $194.2766 \pm$ & $63.4503 \pm$ & $10.4 \pm 0.6^{\mathrm{a}}$ \\
& $2.3829^{\mathrm{b}}$ & $1.2257^{\mathrm{b}}$ & \\
$90 \%$ & $186.2658 \pm$ & $59.7360 \pm$ & $46 \pm 3.5^{\mathrm{b}}$ \\
& $4.4512^{\mathrm{b}}$ & $0.8444^{\mathrm{b}}$ & \\
$110 \%$ & $127.2495 \pm$ & $57.4212 \pm$ & $186 \pm 1.4^{\mathrm{c}}$ \\
& $14.6605^{\mathrm{a}}$ & $0.9608^{\mathrm{a}}$ & \\
$130 \%$ & $110.5480 \pm$ & $58.5961 \pm$ & $286.2 \pm 1.8^{\mathrm{d}}$ \\
& $10.8854^{\mathrm{a}}$ & $2.7117^{\mathrm{a}}$ \\
$150 \%$ & $115.7765 \pm$ & $59.5426 \pm$ & $287,4 \pm 1.2^{\mathrm{d}}$ \\
\multicolumn{4}{c}{} \\
\hline Note:"Means in the same column/row with different superscript differ significantly $(\mathrm{P}<0.05)$.
\end{tabular}

Protein solubility of TVP has significantly increased when mixing time prolong $(\mathrm{P} \leq 0.05)$ (Table 4). The increase of solubility when mixing time increase from $6-9$ minutes is not significantly different. The highest protein solubility results from a TVP process in 18 minutes mixing. Increase of mixing time prolong shear time result in a damage structure of the TVP matrix. The damage structure cause increasing TVP solubity.

The increase of water addition decreases protein solubility. The decrease is not significantly different when water added $80-120 \%(\mathrm{P}>0.05)$. The lowest protein solubility was obtained from TVP with 140\% water addition (Table 4). The increase of water addition probably increases macromolecule interaction in the TVP matrix, that cause decrease of solubility.

The TVP in this research, produced from CSP mixed with XSP. The role of water during extrusion is an enhancement of protein interaction by combining with carbohydrate and act as phase separation. According to [3] and [15], the insoluble fraction of protein responsible for the three-dimensional networking in TVP. Thus, because, disulphide linkages and hydrophobic interactions are dominant protein-protein interaction in the TVP matrix.

\section{CONCLUSION}

The TVP can be made from the mixed of concentrate soy protein and Xanthosoma sagittifolium powder with the application of Houseware pasta machine. XSP proportion, mixing time and water addition are significant factors that affect on water holding capacity, oil holding capacity, texture and protein solubility. The XSP addition, $20 \%$ in to TVP dough have positive effect, increasing $\mathrm{WHC}$, $\mathrm{OHC}$ and decreasing texture. More than $20 \%$ the addition is not recommended because can decrease the TVP properties. In preparing TVP dough, it is not suggested to mix more than 12 minutes. Increasing water addition can decrease water holding capacity, oil holding capacity, protein solubility and increase texture.

\section{ACKNOWLEDGMENT}

This work was financially supported by Research and Technology, Higher Education, Ministry of Indonesia Government

\section{REFERENCES}

[1] G.A. Krintiras, J. Göbel, A.J. Van der Goot and G.D. Stefanidis Production of structured soy-based meat analogues using simple shear and heat in a couette cell. Journal of Food Engineering 160: $34-41$, 2015.

[2] T.J. Maurice and D.W. Stanley. Texture-Structure relationships in texturized soy protein IV. Influence of process variables on extrusion texturization. Canadian Institute of Food Science and Technology Journal, 11, 1-6, 1978.

[3] P.R. Sheard, D.A. Ledward and J.R. Mitchell. Role of carbohydrates in soya extrusion. Journal of Food Technology, 19, 475 - 483, 1984.

[4] K. Rareunrom, S. Tongta and J. Yongsawatdigul. Effects of soy protein isolate on chemical and physical characteristics of meat analog. Asian Journal of Food and Agro-Industry, 1(2), 97 - 104, 2008.

[5] S.A. Senanayake, K.K.D.S. Ranaweera, A. Bamunuarachchi and A Gunaratne. Proximate analysis and phytochemical and mineral constituents in four cultivars of yams and tuber crops in sri lanka Tropical Agricultural Research and Extension 15 (1), 32 - 36, 2012.

[6] C.I. Owuamanam, N.C. Ihediohanma and E.C. Nwanekezi. Sorption isotherm, particle size, chemical and physical properties of cocoyam corm flours. Researcher, 2(8), 11-19, 2010.

[7] C.V. Morr, B. German, J.E. Konsella, J.M. Regenstein, J.P. Van Buren, A. Kilara, B.A. Lewis and M.E. Mangino. A Collaborative study to develop a standardized food protein solubility procedure. Journal of Food Science 50, 1715 - 1718, 1985.

[8] C.F. Chau, P.C.K. Cheung and Y.S. Wong. Functional properties of protein concentrates from three chinese indigenous legume seeds. Journal of Agricultural and Food Chemistry, 45 (7), 2500 - 2503, 1997.

[9] S. Damodaran and A. Paraf. Food proteins and their applications, Marcel Dekker, New York, 1997.

[10] T. Lindriati, Herlina, A. Nafi, Y. Praptiningsih. Prediction of carbohydrate-protein interaction in cassava starch-casein blended 
edible films. Advance Journal of Food Science and Technology 13(7): $272-278,2017$

[11] S.O. Ogunwolu, F.O. Henshaw, H.P. Mock, A. Santros and S.O Awonorin. Functional properties of protein concentrates and isolates produced from cashew (Anacardium occidentale L.) nut. Food Chemistry, 115 (3), 852-858, 2009.

[12] J.M. Manski, E.E.J. van der Zalm, A.J. van der Goot, R.M. Boom. Influence of process parameters on formation of fibrous materials from dense calcium caseinate dispersions and fat. Food Hydrocolloids, 22 (4), 587-600. 2008

[13] A. Chiang. Protein-Protein Interaction of Soy Protein isolate from extrusion processing. A Thesis presented to the Faculty of the Graduate School, University of Missouri, Columbia. 2007

[14] G.J.P. Marsman, H. Gruppen, D.J. Van Zuilichem, J.W. Resink and A.G.J. Voragen. The influence of screw configuration on the in vitro digestibility and protein solubility of soybean and rapeseed meals. Journal of Food Engineering 26: 13 - 28, 1995.

[15] D.F. Hager. Effects of extrusion upon soy concentrate solubility. Journal of Agriculture and Food Chemistry, 32, 293 - 296. 1984. 